Teresa Lubińska, Alberto Lozano-Platonoff, Magdalena Godek, Tomasz Strąk, Marcin Będzieszak

\title{
PERFORMANCE BUDGETING IN POLAND: ACHIEVEMENTS AND FUTURE PERSPECTIVES
}

\section{Introduction}

This article presents Polish performance budget methodology and first results of its implementation. The methodology is based on: the analysis of global achievements and failures in performance budgeting, Polish local governments' performance budget experience, private sector's experience in performance management, audit and accounting experience, experience in managing EU funds and lessons from the pilot projects. The results of the initial implementation stage are: defining tasks and subtasks specifying objectives and measures defined, and linking them with public expenditure, earmarked funds and expenditure of government agencies. At the moment Polish Ministry of Finance continues performance budgeting implementation on a basis of methodology presented in this article.

In November 2007 the World Bank prepared an assessment report on performance budgeting in Poland. In the comments concluding the document it was stated that "Poland has made considerable and praiseworthy progress in the development of enhanced performance budgeting which focuses on outcome and responsibility". It was emphasized that when developing a concept for Poland, the authors derived from the practice and experience of several European countries and OECD member states. This approach was considered practical, and appropriate for Poland's situation. D. Webber argues that the 2008 performance budget is constructed correctly in most of the key areas, including at the same time international best practices within state budget management. 


\section{Definition of a performance budget}

In the authors' opinion the essence of the performance budget consists in introducing the management of public funds by objectives that are properly specified and arranged in order to achieve specific results measured using a defined system of measures ${ }^{1}$.

In the performance budget it is possible to decide which tasks are most relevant to the implementation of specific objectives, and its measures show to what extent they have been achieved.

Table 1 presents the major differences between the traditional budget and the performance budget in Poland.

Table 1. Basic characteristics of the traditional and performance budgets

\begin{tabular}{|c|c|}
\hline Traditional Budget & Performance Budget \\
\hline Spending Tool & Governance Tool \\
\hline $\begin{array}{l}\text { Difficult definition of the relationship between the state } \\
\text { expenditure and its objectives and tasks - traditional } \\
\text { classification }\end{array}$ & $\begin{array}{l}\text { Makes it possible to establish a relationship between } \\
\text { expenditure and objectives and tasks thus allowing } \\
\text { functional arrangement of expenditure by tasks - new } \\
\text { classification }\end{array}$ \\
\hline $\begin{array}{l}\text { No relationship between expenditure and the } \\
\text { effectiveness and efficiency categories }\end{array}$ & $\begin{array}{l}\text { Management of expenditure towards better effectiveness } \\
\text { and efficiency through an evaluation system }\end{array}$ \\
\hline $\begin{array}{l}\text { No long-term prediction of expenditure earmarked for } \\
\text { individual tasks }\end{array}$ & $\begin{array}{l}\text { Long-term approach - a three-year projection of } \\
\text { expenditure for controllers by tasks }\end{array}$ \\
\hline No integration of expenditure & $\begin{array}{l}\text { Global approach to public sector expenditure - } \\
\text { consolidation by tasks }\end{array}$ \\
\hline Difficult ranking of expenditure by relevance & $\begin{array}{l}\text { Hierarchy of expenditure and instruments according to } \\
\text { their relevance to the government's tasks }\end{array}$ \\
\hline Ministry-based approach & $\begin{array}{l}\text { Encourages cooperation between ministries and other } \\
\text { public sector institutions }\end{array}$ \\
\hline $\begin{array}{l}\text { No clear information about departmental spending policy } \\
\text { in ministries - low transparency }\end{array}$ & $\begin{array}{l}\text { Clear information about expenditure classified by tasks } \\
\text { makes it possible to communicate with the public }\end{array}$ \\
\hline $\begin{array}{l}\text { Parliamentary discussion focusing on single expenditure } \\
\text { items }\end{array}$ & $\begin{array}{l}\text { Makes it possible to conduct a parliamentary technical } \\
\text { discussion on the government's priority tasks }\end{array}$ \\
\hline
\end{tabular}

Source: own study

1 T. Lubińska, A. Lozano Platonoff, T. Strąk, Budżet zadaniowy - racjonalność-przejrzystość-skuteczność, „Ekonomista”, No 5, 2006. Por. A. Schick, Budgeting For Results: Recent Developments In Five Industrialized Countries, "Public Administration Review", January/February, 1990, P. Joyce, Future of federal budgeting: What will the government do? How will it make its choices?, "Journal of Public Budgeting, Accounting \& Financial Management”, Spring 1997, K. Willoughby, Performance Measurement and Budget Balancing: State Government Perspective, "Public Budgeting \& Finance", Summer 2004, T. Carlin, Output Based Budgeting \& the Management of Performance, "Macquarie Graduate School Of Management Working Papers In Management", WP 2004-7, D. Kong, Performance-Based Budgeting: The U.S. Experience, "Public Organization Review: A Global Journal" 2005. 
Performance Budgeting in Poland: Achievements and Future Perspectives

Fig. 2. Performance budget - budget and performance spheres

Traditional state budget

\begin{tabular}{|c|c|c|c|}
\hline Part & Section & Chapter & Expenditure \\
\hline $\mathbf{X X}$ & & Name of part & $\mathbf{1 2 5 8 3 2 0}$ \\
\hline & $Y Y Y$ & Name of section & 468767 \\
\hline $\mathbf{X X}$ & YYYZZ & Name of chapter & 1100 \\
\hline & & Name of part & $\mathbf{3 9 0 8 3 3 6}$ \\
\hline
\end{tabular}

\begin{tabular}{|c|c|c|c|c|c|c|c|c|c|c|}
\hline \multicolumn{11}{|c|}{ Performance budget } \\
\hline \multirow{11}{*}{ 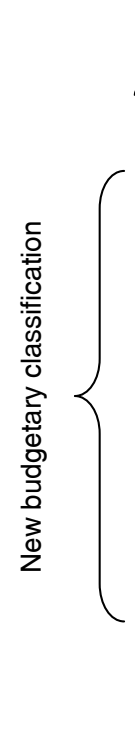 } & \multicolumn{4}{|c|}{ Budget sphere } & \multicolumn{6}{|c|}{ Performance sphere } \\
\hline & & & pendit & & & & & & & \\
\hline & & 2008 & 2009 & 2010 & Objective & Indicator & Base & 2008 & 2009 & 2010 \\
\hline & Task 1 & & & & & & & & & \\
\hline & Subtask 1.1 & & & & & & & & & \\
\hline & Subtask 1.2 & & & & & & & & & \\
\hline & Subtask 1.3 & & & & & & & & & \\
\hline & Task 2 & & & & & & & & & \\
\hline & Subtask 2.1 & & & & & & & & & \\
\hline & Subtask 2.2 & & & & & & & & & \\
\hline & Subtask 2.3 & & & & & & & & & \\
\hline
\end{tabular}

Source: own study 
Performance budgeting is a broader concept than traditional budgeting, as it covers the so-called performance part which supports long-term management by objectives.

Modern performance-oriented management of public expenditure is a challenge for Central and Eastern European Countries. The expenditure becomes an especially strong instrument of socio-economic policy in the integrated European Union. Common currency narrows the range of instruments of the monetary and fiscal policy that includes interest rates, exchange rates, taxes, expenditure, budget deficit and public debt. It is public expenditure that starts to play the major role; taxes are being harmonized, whereas the budget deficit and public debt are subject to limitations imposed by the Maastricht Treaty ${ }^{2}$.

The aim of introducing performance budgeting in Poland is to facilitate e.g. the maintenance of a low deficit and implementation of the Lisbon Strategy. It is therefore included in the Convergence Programme and the National Reform Programme Implementation Document. The Convergence Programme developed in the years $2005 / 2006$ stated in a chapter on public finance that "The government has begun to work on the proposal to implement a performance budget. This new structure of the budget should become a tool supporting efficient management of public expenditure to ensure more transparency. Gradual performance-oriented approach to budget expenditure (or the entire public expenditure) should involve development of a long-term budget planning system in Poland. This long-term approach will enable government units to develop programmes oriented at accomplishment of certain tasks and to define the target level of expenditure in those programmes." The same regulations have been introduced to the Convergence Programme 2008.

The reform implementing the performance budget as a modern system of management of public expenditure is a long-term project. The implementation itself is part-financed by the European Union. The following amounts of expenditure are planned for the years 2007-2013 in connection with the process of implementing performance budgeting in the Polish public sector:

- EUR 64.3 million within the "Human Capital" Operational Programme Priority V "Good Governance" and within the HC OP technical assistance;

- EUR 10 million within the "Innovative Economy" Operational Programme Priority VII "Building and Development of an Information Society". 


\section{Methodological foundations of the performance budgeting reform}

Developing the methodology to construct a performance budget and defining the principles which the new budgeting system should meet requires a multidimensional analysis of experience in long-term budget planning and programming, and management by objectives in both public and private sector. Public finance systems vary with the country thus making it impossible to simply transfer foreign solutions to Poland without modifying them.

The methodological foundations of the performance budgeting reform were published for the first time in $2006^{3}$. The new system was developed after a careful analysis of $f^{4}$ :

1) Global successes and failures in performance budgeting - literature study, visits to ministries of finance in selected countries, WB's and IMF's reports;

2) Experience in performance budgeting in Polish local governments ${ }^{6}$ and tax administration ${ }^{7}$

3) Experience in management by objectives in the private sector ${ }^{8}$;

3 T. Lubińska, A.Lozano,... op.cit.

4 T. Lubińska, T. Strąk, A. Lozano Platonoff, M. Będzieszak, Metodologiczne i wdrożeniowe aspekty zastosowania budżetu zadaniowego, „Ekonomista”, No. 5, 2007.

5 R. Kaplan, The Balanced Scorecard for Public-Sector Organizations, "Harvard Business Review",1999, R. Kaplan, Overcoming the Barriers to Balanced Scorecard Use in the Public Sector, "Harvard Business Review", 2000, P. Knaap van der, Performance Management and Policy Evaluation in the Netherlands - Toward an Integrated Approach, "Evaluation", vol. 6(3) 2000, R. Allen, D. Tommasi, (eds). Managing Public Expenditure. A Reference Book for Transition Countries. OECD, 2001, I. Joumard, P. Kongsrud, Y.S. Nam, R. Price, Enhancing the Effectiveness of Public Spending: Experience in OECD Countries. OECD Economics Department Working Papers, No. 380, OECD, 2004, D. Webber, Managing the Public's Money: From Outputs to Outcomes - and Beyond. OECD Journal of Budgeting vol. 4 no. 2, Paris, 2004, M. Bouvier, M. Esclassan, J-P Lassale, Finance Publiques, LGDJ, 2006, J. Diamond, Budget System Reform in Emerging Economies. The Challenges and the Reform Agenda. International Monetary Fund, Washington DC, 2006, A. Lambert, Une première expérience riche d'enseignement'. Revue Française de Finances Publiques, No. 94, 2004, M. Robinson, Making Performance Budgeting Work in M. Robinson, M. (ed.). Performance Budgeting. Linking Funding and Results. International Monetary Fund-Palgrave-Macmillian 2007, Models of Public Budgeting and Accounting Reform, OECD Journal on Budgeting vol.2, supplement 1, OECD 2002.

6 Pakonski, K. (ed.). Budżet - zintegrowane zarządzanie finansami. Municipium, Warsaw 2000, M. Kosek-Wojnar, K. Surówka, Finanse samorządu terytorialnego. Wydawnictwo Akademii Ekonomicznej w Krakowie, Cracow 2004, Owsiak, S. (ed.). Budżet władz lokalnych, Polskie Wydawnictwo Ekonomiczne, Warsaw 2002, J. Bober, A. Władyka, M. Zawicki, (eds.). Katalog narzędzi rozwoju instytucjonalnego Małopolska Szkoła Administracji Publicznej, Cracow 2004, Lubińska, T., Strategia rozwoju samorządów a program gospodarczy i budżet samorządów, Zeszyt Naukowy US No. 385, Prace Katedry Finansow No. 12, Szczecin 2004, p. 117-132, Misiag, W. (ed.). Wzorcowy urząd, czyli jak usprawnić administracje samorządowa, jak mierzyć jej zadania i wyniki. IBnGR, Warsaw 2005.

7 E. Ruśkowski, Kilka uwag o reformie administracji skarbowej w aspekcie reformy finansów publicznych in: J. Głuchowski, A. Pomorska, J. Szołno-Koguc (eds) Uwarunkowania i bariery w procesie naprawy finansów publicznych, Wydawnictwo KUL, Lublin 2007,s. 261-266.

8 A. Lozano-Platonoff, System dynamicznego zarządzania przedsiębiorstwem. Rozprawy studia T. (DXCV) 521, Uniwersytet Szczecinski, Szczecin 2005. 
4) Experience in auditing and accounting;;

5) Experience in administering EU funds ${ }^{10}$;

and:

6) Conclusions reached after pilot studies carried out by: the Ministry of Science and Higher Education, the Ministry of Education, the Ministry of Labour and Social Policy, the Interministerial High-Tech Programme.

A traditional budget is a plan of income and expenditure, revenue and outgoings. The expenditure is classified in appropriate components of the budget classification - parts, sections and chapters.

As already mentioned, performance budgeting is a broader concept, as it includes the so-called performance part supporting long-term management by objectives.

For each part of the budget, the methodology of performance budgeting identifies the following levels of classification: tasks and subtasks which are the responsibilities of appropriate units and group the expenditure by objectives, including targets. This performance classification is based on activities - the expenditure and costs by paragraphs of the budget classification.

A task is a major unit which groups separate areas of activity of the controller so that each task can be assigned one or more objectives, together with efficiency and effectiveness measures. The task becomes, therefore, a multi-purpose category supporting management, budgeting and accounting.

The definition of tasks was considered in the performance budgeting methodology in Poland as a starting point for implementing performance budgeting. Ministries become the authors of their own classifications as those who are most aware of their information needs. The breakdown of the budget into a certain number of tasks and subtasks was a resultant of flexibility in activity (spending), stabilization of the classification and clarity - each budget part was broken down into 4 to 7 tasks. Each ministry has its own list of tasks.

The methodology of performance budgeting anticipates the definitions of objectives and measures for individual tasks and subtasks. The measures quantify the objectives to evaluate their achievement. Depending on the data and type of the task, output, outcome or impact measures were employed. The process requires

9 K. Czubakowska, Budżetowanie w controllingu, ODiDK Gdansk 2004, T. Strąk, Wyrywkowe badania w audycie wewnętrznym, Wydawnictwo Economicus, Szczecin 2005. T. Strąk, Sekwencyjne próbkowanie według jednostek pieniężnych in Standaryzacja rachunkowości i rewizji finansowej według MSSF i MSRF, Krajowa Izba Biegłych Rewidentów, Warsaw 2006.

10 Working Paper 3. Indicators for monitoring and evaluation - an indicative methodology, European Commission, 1999. 
appropriate knowledge, systems of gathering and analysis of information as well as experience.

The methodology of performance budgeting assumes that measures will become more and more important with time. Two stages of development and implementation of measure in performance budgeting were identified:

- Stage I - the years 2008 and 2009 (at least) - measures are instruments both accepted by the Minister of Finance and line-minister (heads of departments) and helpful in governing;

- Stage II - measures are instruments which are not only acceptable and helpful in governing but also support distribution of resources in the budget. The stimulating and controlling role of measures should be anticipated within 23 years following the implementation of the complete performance budget.

An important role in the implementation of performance budgeting and assuring the best effects in improvement in managing public expenditure should be played by the Supreme Chamber of Control and internal auditing. Interesting in this aspect seems the experience of Supreme Chamber of Control in the Netherlands ${ }^{11}$.

Each budget task can be assigned directly the cost of employing resources (both human and tangible) essential to perform that task, the amounts transferred within the task to final recipients and capital expenditure. While allocating direct expenditure to individual tasks it is important to bear the essentiality principle in mind. It is not advisable to strive to allocate all the costs of implementing a given task to that task but only those costs that will be regarded as essential because of their amount or type. For example, the allocation of paper or electric energy consumption costs to individual tasks may turn out to be unprofitable because it will be necessary to extend the record system for those costs and because they are small.

It should also be mentioned that the methodology of performance budgeting separates the task "policy development and coordination". This task accounts for the expenditure on general activities, common for the tasks performed for the entire part of the budget or a unit performing tasks, which cannot be directly assigned to individual tasks. They refer mostly to management, or administrative and technical service of the controller, in particular:

1) coordination of the controller's activity, strategic and operational planning, or consulting for the minister, province governor or head of a central office;

2) administration of tasks (for instance: HR department, accounting, controlling and auditing, archive, health and safety, civil defense);

11 P. Knaap van der, Responsive Evaluation and Performance Management, "Evaluation", Vol. 12 (3), $2006 .$, pp. 278-293. 
3) technical service (transportation, IT, security, cleaning, repair, maintenance).

Public expenditure in the performance budget is organized so that it refers to individual tasks, objectives and measures. A performance budget should answer five basic questions: what tasks are performed by ministries and central offices?; how much does the society spend on individual tasks?; what are the major objectives?; what effects are expected?; to what extent have the objectives been achieved? The answers to those questions comply with the standards of transparency set by the $\mathrm{IMF}^{12}$, including those concerning tasks and responsibility. The questions formed a methodological framework for performance budgeting, expressed in the following principles: transparency, efficiency, effectiveness, consolidation of expenditure, and a long-term approach ${ }^{13}$.

According to the framework of performance budgeting presented above, in 2006 Articles 124 and 158 of the Act on Public Finance were amended to their present version:

"Art. 124. The budget act should be accompanied by a justification that contains in particular:

9) A list of tasks, within the planned amounts of expenditure, along with the description of their objectives, performance measures and anticipated long-term financial costs of their implementation

Art. 158. 3. The budget execution report should present:

9) information about task performance, within the planned amounts of expenditure, along with the description of their objectives, performance measures and anticipated long-term financial costs of their implementation as well as expenditure on their implementation."

Modern management of expenditure by means of performance budgeting, which answers the above questions, should be based on the following planning documents: guidelines for long-term performance budgeting (including the government's priorities), a three-year projection of expenditure, an annual budget and plans of activities (see: Fig. 2). Following the reform, the initial implementation of longterm performance budgeting was expected in the year 2009.

It should be emphasised that C. Kosikowski developed a draft amendment to the Act of 30 June 2005 on Public Finance (Journal of Laws 2005, No. 249, Item 2104, as amended) based on performance budgeting. It included, in particular, the introduction of new planning documents accompanying the annual budget 
(introduction of Part II to the Act on Public Finance) allowing long-term budget management:

a) Guidelines for long-term performance budgeting;

b) Three-year projection of income;

c) Three-year projection of public expenditure by tasks, including tasks, objectives and measures;

d) Interministerial task programmes;

e) Annual public expenditure consolidation plan;

f) Annual plans of activities.

According to the draft Act on Public Finance, which Polish Ministry of Finance is currently working on, controllers responsible for individual budget parts would be obliged to develop a plan of income and expenditure for the given budget year and the following two years. The two-year planning cycle proposed was an effect of broad consultation with a number of experts in public finance and budgeting practitioners.

Fig. 2. System of planning documents and their interrelations in Poland

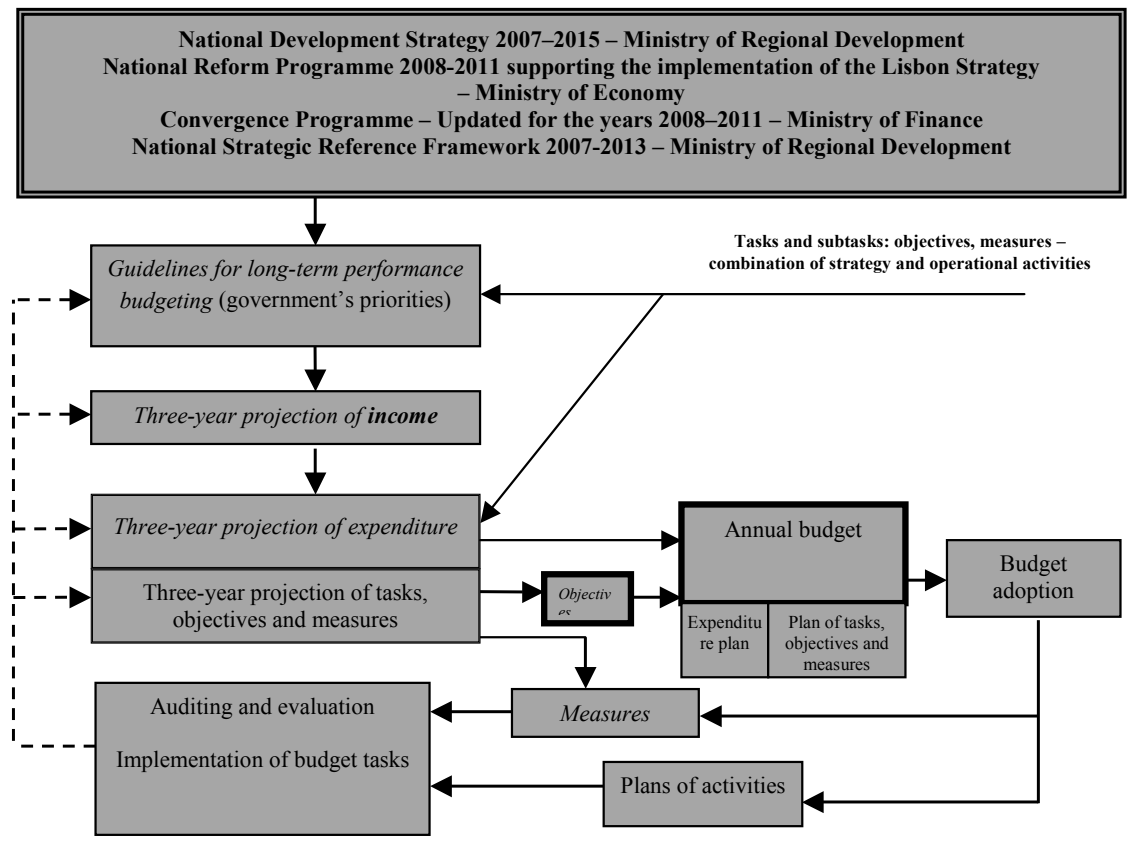

Source: T. Lubinska (ed), Budzet..., op. cit, p. 63. 
It was assumed that the above documents would be required starting from the 2010 budget. From that year on, budgeting in Poland would be based on three-year strategic planning replacing the existing short-term approach to decision making concerning expenditure.

\section{Effects of work on the performance budgeting reform observed in the years 2006-2007}

The first version of the performance budget was prepared for the year 2008. The budget was presented in a short version in the justification of the draft budget act 2008. The full version of the performance budget was included in the Performance Budget Report ${ }^{14}$ consisting of two volumes: Vol. 1. Performance Budget 2008, and Vol. 2. Description of performance budgets of controllers of individual parts of the 2008 budget. Performance budgeting includes:

- public expenditure for the year 2008 by tasks - 166 tasks and 454 subtasks expenditure plan in the performance budget,

- list of expenditure specifying tasks, objectives and measures -656 objectives and 957 measures - performance part of the performance budget,

- consolidated public expenditure, earmarked funds and expenditure of government agencies for tasks and subtasks totaling PLN 161,287,702,000,

- linking the traditional and performance budgets - allocation of expenditure to individual tasks.

According to the requirements of the budget notification, budget controllers prepared, for the first time, a two-year projection of expenditure for the years 20092010.

Performance budget 2008 allowed for the expenditure of 118 controllers, classified into 132 budget parts, 19 earmarked funds and 7 state legal persons, as referred to in the Art. 4 para. 1 item 12 of the Act on Public Finance (i.e. the Office of Technical Inspection, the Polish Center for Accreditation, the Polish Agency for Enterprise Development, the Material Reserve Agency, the Transportation Technical Supervision, the Military Property Agency, the Military Housing Agency).

It should be emphasized here that province governors' performance budgets include up to 34 tasks to be performed on the regional level, in relation to the

Raport Budżet zadaniowy. Tom I - Budżet zadaniowy na rok 2008, Kancelaria Prezesa Rady Ministrów, Warsaw 2007, Raport Budżet zadaniowy. Tom II - Omówienie budżetów zadaniowych dysponentów części budżetowych na rok 2008. Kancelaria Prezesa Rady Ministrów, Warsaw 2007. 
responsibilities of various ministries. It should come as no surprise that the tasks performed by the governors correspond with the subtasks of individual ministries.

Performance budget does not allow for the expenditure made by the following budget parts: 01. the Chancellery of the President of the Republic of Poland, 02. the Chancellery of the Sejm, 03. the Chancellery of the Senate, 04. the Supreme Court, 05. the Supreme Administrative Court, 06. the Constitutional Tribunal, 08. the Commissioner for Civil Rights Protection, 09. the National Broadcasting Council, 10. the National Data Protection Supervisor, 11. the National Election Office, 13. the Institute of National Remembrance - Commission for the Prosecution of Crimes against the Polish Nation, 14. the Commissioner for Children's Rights Protection, 16. the Chancellery of the Prime Minister, 52. the National Council of the Judiciary, 72. the Agricultural Social Insurance Fund, 73. the Social Insurance Institution, 75. the Government Legislation Center, 78. Foreign debt service, 79. National debt service, 81. General reserve, 82. Subsidies for local governments, 83. Special purpose reserves, 84. contribution to the EU budget, totaling PLN 173,689,152,000.

Those parts were considered to be included in the second stage of implementing performance budgeting. A part of this expenditure was not included due to its nature, e.g. 78. Foreign debt service, 79. National debt service, 82. Subsidies for local governments.

To illustrate the effects of the works on performance budgeting, the draft version of the budget prepared by the Ministry of Economy in the traditional and performance-oriented form has been presented in Table 2 .

The Minister of Economy administers only one part of the budget-20. Economy. Within this part, four major tasks are separated. In the traditional budget part 20 consists of 7 sections and 20 chapters, whereas the "Other activity" chapter appears three times. Other chapters indicate mainly institutions which receive resources from part 20, or sectors of the economy but the information is too general to allow detailed identification of the tasks performed e.g. within mining. 
T. Lubińska, A. Lozano-Platonoff, M. Godek, T. Strąk, M. Będzieszak

Table 2. Traditional and performance budgets for the part Economy

Traditional budget (PLN thousand)

\begin{tabular}{|c|c|c|c|c|}
\hline 20 & \multicolumn{3}{|r|}{ ECONOMY } & \multirow{3}{*}{$\begin{array}{c}2021152 \\
448713 \\
370500\end{array}$} \\
\hline & \multirow[t]{2}{*}{100} & \multicolumn{2}{|r|}{ Mining and quarrying } & \\
\hline & & 10001 & Hard coal mining & \\
\hline & & 10002 & Brown coal mining & 2 \\
\hline & & 10005 & Production of salt & 66000 \\
\hline & & 10095 & Other activity & 12211 \\
\hline & 150 & \multicolumn{2}{|r|}{ Manufacturing } & 925357 \\
\hline & & 15006 & Metallurgy & 100 \\
\hline & & 15011 & Enterprise development & 21013 \\
\hline & & 15012 & Polish Agency for Enterprise Development & 351181 \\
\hline & & 15095 & Other activity & 553063 \\
\hline & \multirow[t]{2}{*}{500} & \multicolumn{2}{|r|}{ Trade } & 390963 \\
\hline & & 50003 & Material Reserve Agency & 312040 \\
\hline & & 50005 & Promotion of exports & 78923 \\
\hline & 750 & \multicolumn{2}{|r|}{ Public administration } & 189728 \\
\hline & & 75001 & Offices of central government administration bodies & 107283 \\
\hline & & 75057 & Foreign posts & 68325 \\
\hline & & 75061 & Centre for Eastern Studies & 7117 \\
\hline & & 75095 & Other activity & 7003 \\
\hline & 752 & \multicolumn{2}{|r|}{ National defence } & 62726 \\
\hline & & 75212 & Other defence expenditure & 726 \\
\hline & & 75215 & $\begin{array}{l}\text { Tasks related to maintaining reserves for the needs of Polish } \\
\text { Army }\end{array}$ & 62000 \\
\hline & 754 & \multicolumn{2}{|r|}{ Public security and fire fighting } & 40 \\
\hline & & 75417 & NATO & 40 \\
\hline & 900 & \multicolumn{2}{|r|}{ Public utilities and environmental protection } & 3625 \\
\hline & & 90011 & $\begin{array}{c}\text { National Fund for Environmental Protection and Water } \\
\text { Management }\end{array}$ & 3625 \\
\hline
\end{tabular}


Performance Budgeting in Poland: Achievements and Future Perspectives

Performance budget (PLN thousand)

\begin{tabular}{|c|c|c|}
\hline & MINISTER OF ECONOMY & 2021152 \\
\hline & Part 20. Economy & 2021152 \\
\hline 1. & Improvement in the economy's competitiveness, of which: & 750073 \\
\hline 1.1. & Better quality of legal regulations concerning business activity & 5974 \\
\hline 1.2. & Providing favourable conditions for supporting innovation & 270220 \\
\hline 1.3. & Providing favourable conditions for supporting development of enterprises & 352981 \\
\hline 1.4. & $\begin{array}{l}\text { Implementation of the principle: focus on micro, small and medium-sized } \\
\text { enterprises }\end{array}$ & 120898 \\
\hline 2. & $\begin{array}{l}\text { Diversification of energy supply sources and methods of energy } \\
\text { production, of which: }\end{array}$ & 413676 \\
\hline 2.1. & $\begin{array}{l}\text { Diversification of energy supply sources and development of new transmission } \\
\text { and transport capacities for electricity, natural gas and crude oil and expansion } \\
\text { of underground natural gas stock }\end{array}$ & 6745 \\
\hline 2.2. & Providing favourable conditions for effective operations of hard coal mining & 383157 \\
\hline 2.3. & Improvement in energy efficiency & 13710 \\
\hline 2.4. & $\begin{array}{l}\text { Intensification of use of renewable energy sources and liquid biofuels in } \\
\text { transport }\end{array}$ & 10064 \\
\hline 3. & Internationalisation of Polish economy, of which: & 431810 \\
\hline 3.1. & $\begin{array}{l}\text { Contribution to development of economic and common trade policies of the } \\
\text { European Union respecting Poland's interests }\end{array}$ & 131766 \\
\hline 3.2. & Economic promotion of Poland & 111884 \\
\hline 3.3. & Intensification of trade exchange of goods, services and capital & 29391 \\
\hline 3.4. & Development of an investor-supporting system & 158769 \\
\hline 4. & Tasks related to national security, of which: & 377196 \\
\hline 4.1. & Economic potential for the needs of national security & 314718 \\
\hline 4.2. & Maintaining production capacity for the needs of national defence & 62478 \\
\hline 5. & Policy development and coordination, of which: & 48397 \\
\hline 5.1. & Coordination of the Ministry's activities & 15353 \\
\hline 5.2. & Coordination of the National Reform Programme & 452 \\
\hline 5.3. & Administrative and technical service of the Ministry's activities & 32592 \\
\hline
\end{tabular}

Own study based on: Raport Budżet zadaniowy. Tom I- Budżet zadaniowy na rok 2008, Kancelaria Prezesa Rady Ministrów, Warsaw 2007, p. 52-53 and a draft budget act 2008. 
Performance budget aims to improve the efficiency of performing public tasks and to raise the effectiveness of public expenditure. It would therefore be essential to identify the objectives of public expenditure earmarked for individual tasks and subtasks and their measures.

In many cases the measures proposed raise certain reservations. It should not be forgotten, however, that it is the first attempt to define measures for public tasks in Poland, and so they should be subject to natural verification and enhancement focusing on developing a closer link to objectives.

Table 3 presents the objectives and measures for tasks and subtasks performed by the Minister of Economy.

In the case of the task "Diversification of energy supply sources and methods of energy production" and relevant subtasks, we are dealing with all the three types of measures: output, outcome and impact. For the subtask 2.1 output measures were employed, for subtask 2.2 - outcome measures, and for the remaining subtasks 2.32.4 as well as the task 2 itself - impact measures. 


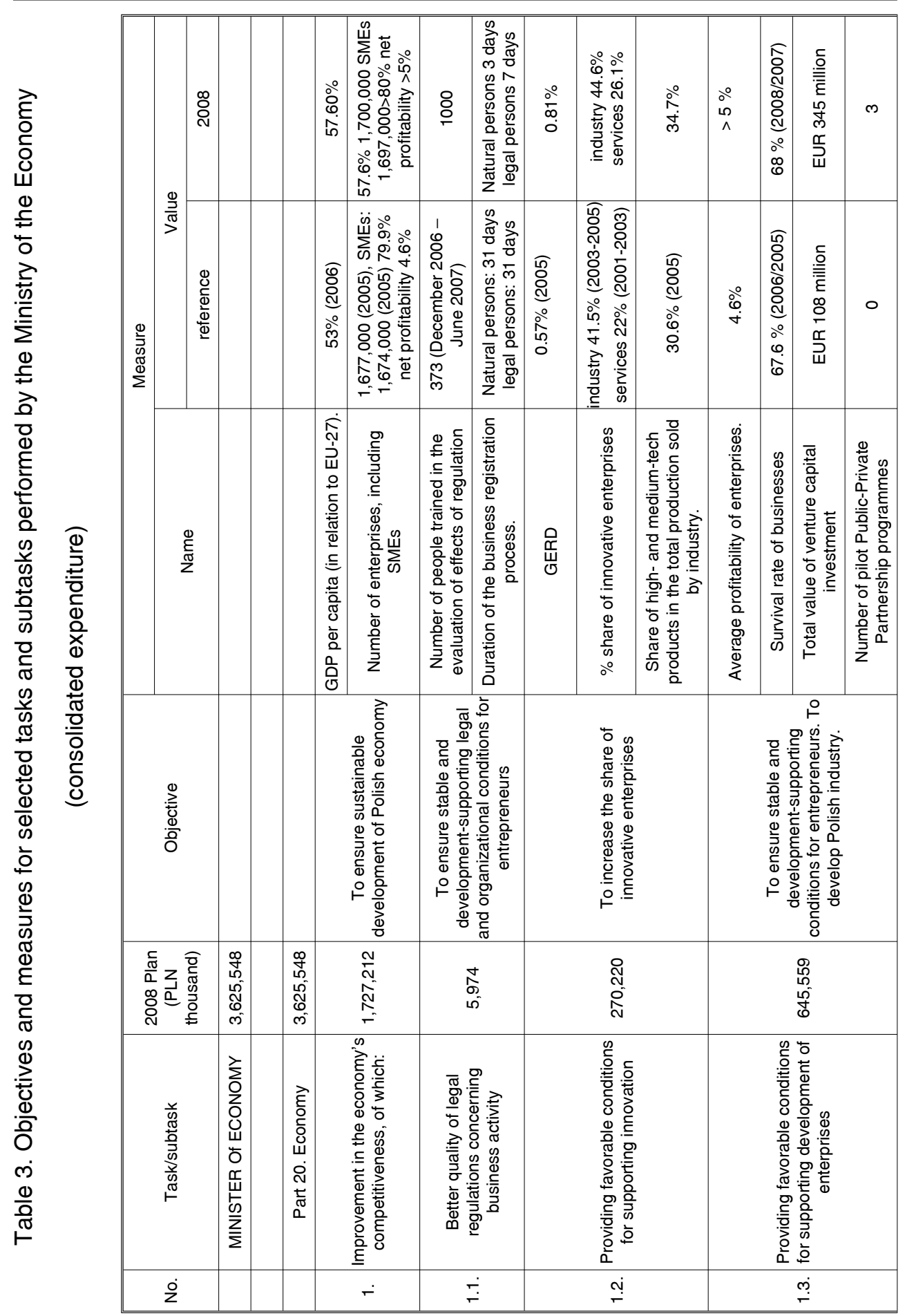


T. Lubińska, A. Lozano-Platonoff, M. Godek, T. Strąk, M. Będzieszak

\begin{tabular}{|c|c|c|c|c|c|c|c|c|c|c|c|c|c|}
\hline ठ̊ํํ & 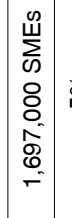 & 总 & ถัำ & 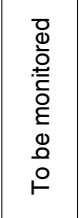 & 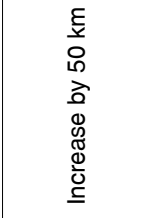 & 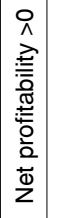 & i & 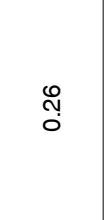 & ڤ̊ำ & $\mid \begin{array}{l}\stackrel{\circ}{\circ} \\
\text { î̉ }\end{array}$ & 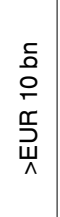 & $\frac{\stackrel{\circ}{\circ}}{\bar{v}}$ & م \\
\hline 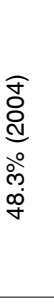 & 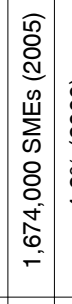 & 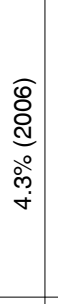 & 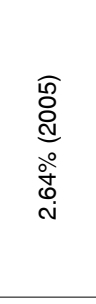 & 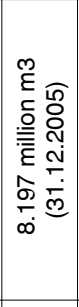 & 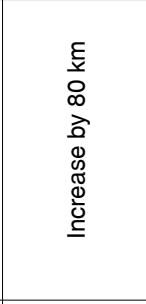 & 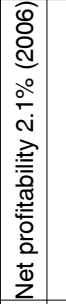 & 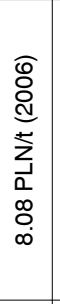 & 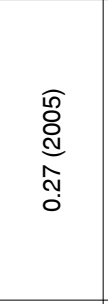 & 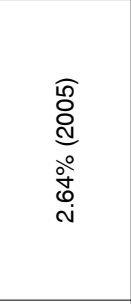 & \begin{tabular}{|c|}
$\widehat{\widehat{o}}$ \\
$\stackrel{d}{d}$ \\
$\stackrel{\circ}{\circ}$ \\
$\stackrel{\circ}{\mathrm{j}}$ \\
d.
\end{tabular} & 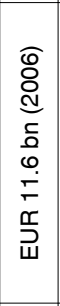 & 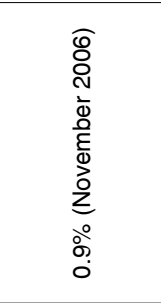 & 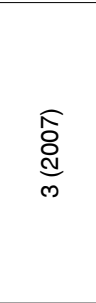 \\
\hline 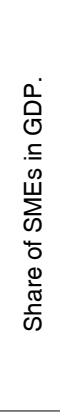 & 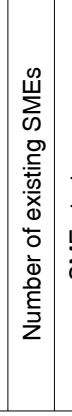 & 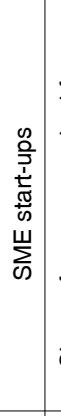 & 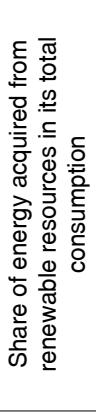 & 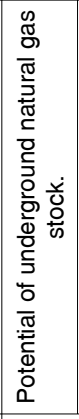 & 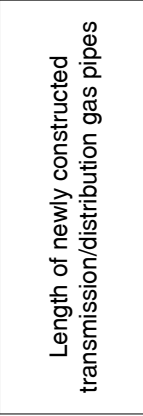 & 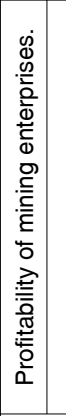 & 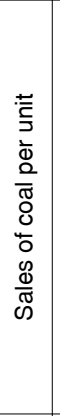 & 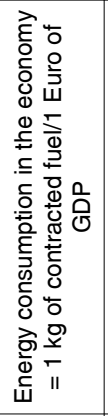 & 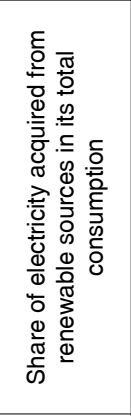 & 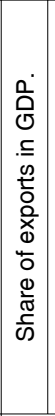 & 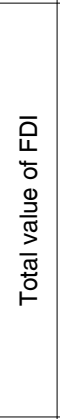 & 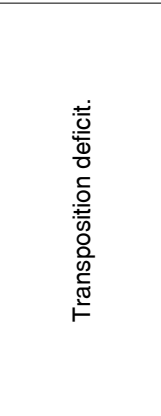 & 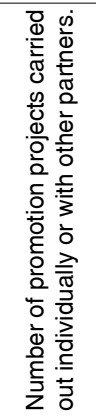 \\
\hline \multicolumn{3}{|c|}{ 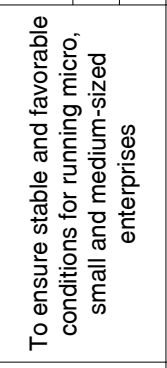 } & 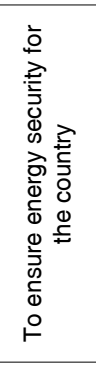 & \multicolumn{2}{|c|}{ 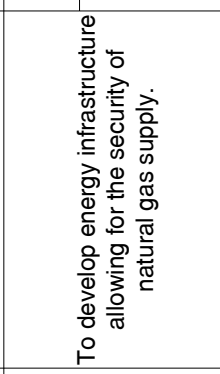 } & \multicolumn{2}{|c|}{ 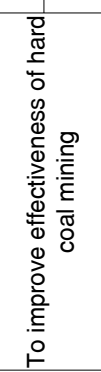 } & 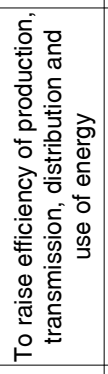 & 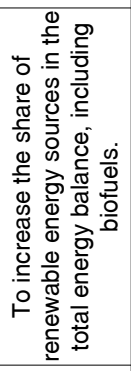 & \multicolumn{2}{|c|}{ 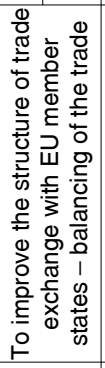 } & 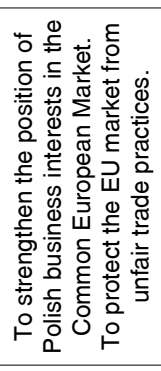 & 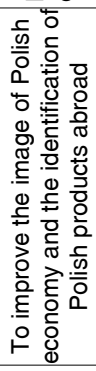 \\
\hline \multicolumn{3}{|c|}{ 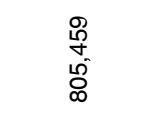 } & \begin{tabular}{l}
0 \\
6 \\
0 \\
\multirow{\sigma}{\sigma}{}
\end{tabular} & & $\frac{\stackrel{L}{\stackrel{2}{*}}}{0^{\circ}}$ & & & $\begin{array}{l}\stackrel{0}{N} \\
\stackrel{m}{ }\end{array}$ & $\begin{array}{l}\text { ष् } \\
: \\
0\end{array}$ & \multicolumn{2}{|c|}{$\begin{array}{l}\frac{0}{\infty} \\
\infty \\
\frac{-}{9}\end{array}$} & $\begin{array}{l}\& \\
\stackrel{\varrho}{-} \\
\stackrel{m}{-}\end{array}$ & 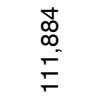 \\
\hline \multicolumn{3}{|c|}{ 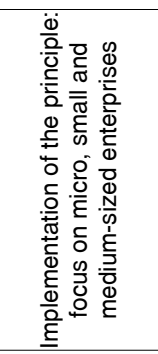 } & 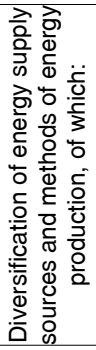 & 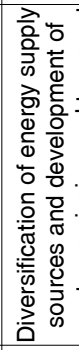 & 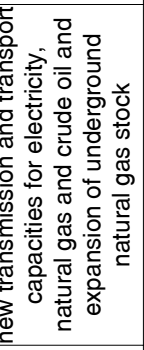 & 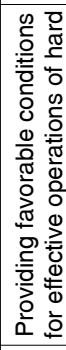 & 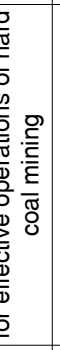 & 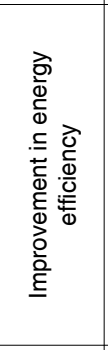 & 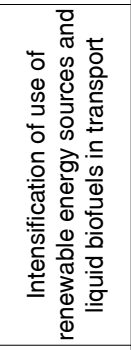 & \multicolumn{2}{|c|}{ 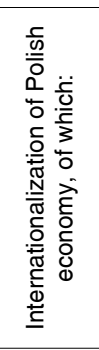 } & 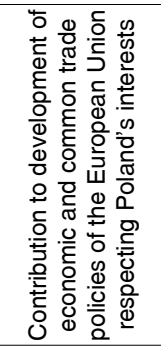 & 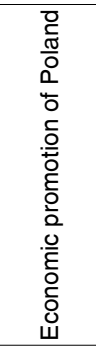 \\
\hline \multicolumn{2}{|c|}{$\stackrel{+}{+}$} & & & & $\overline{\mathrm{N}}$ & N & & N & ง & \multicolumn{2}{|c|}{$\dot{m}$} & $\dot{\bar{m}}$ & $\begin{array}{l}\text { Nִ } \\
\text { m. }\end{array}$ \\
\hline
\end{tabular}


Performance Budgeting in Poland: Achievements and Future Perspectives

\begin{tabular}{|c|c|c|c|c|c|c|c|c|}
\hline 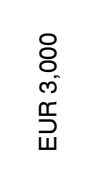 & 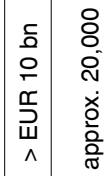 & 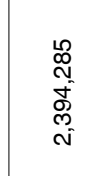 & 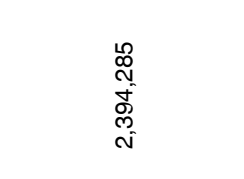 & $\stackrel{?}{N}$ & & & & \\
\hline 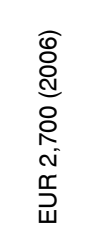 & 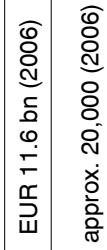 & \begin{tabular}{l} 
O \\
$\bar{N}$ \\
\multirow{N}{\alpha}{} \\
$\stackrel{-}{-}$
\end{tabular} & $\begin{array}{l}\text { O } \\
\bar{N} \\
\text { N̦ } \\
\stackrel{-}{-}\end{array}$ & 0 & & & & \\
\hline 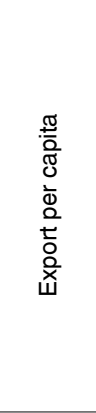 & 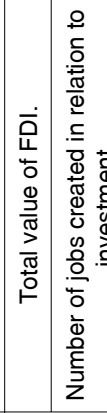 & 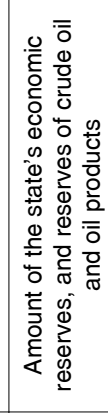 & 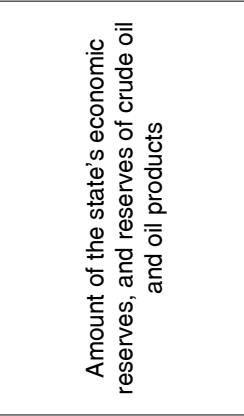 & 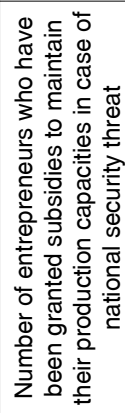 & & & & \\
\hline 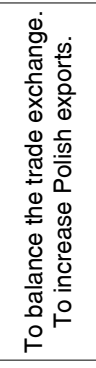 & 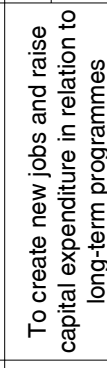 & 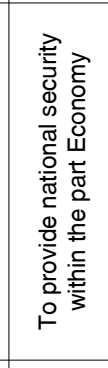 & 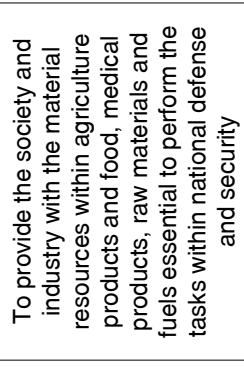 & 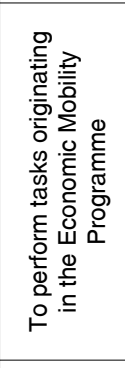 & 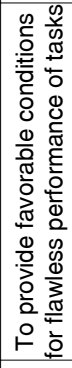 & & 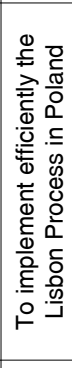 & \\
\hline $\begin{array}{l}\bar{్} \\
\text { ल } \\
\text { N̦ }\end{array}$ & $\begin{array}{l}\stackrel{\circ}{\circ} \\
\text { ô } \\
\text { مी } \\
\stackrel{2}{2}\end{array}$ & 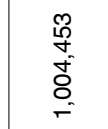 & 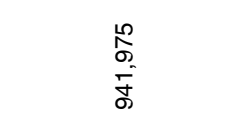 & 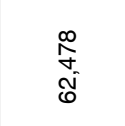 & $\begin{array}{l}\hat{\$} \\
\text { య } \\
\text { o }\end{array}$ & 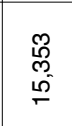 & ָั & 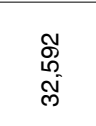 \\
\hline 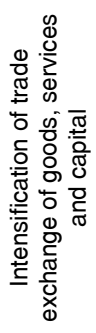 & 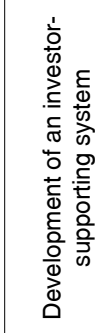 & 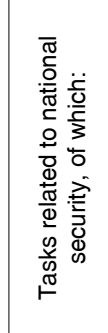 & 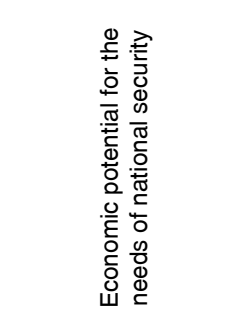 & 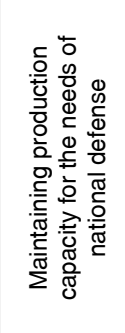 & 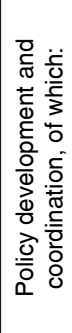 & 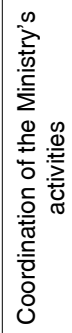 & 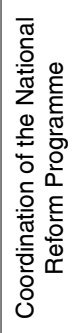 & 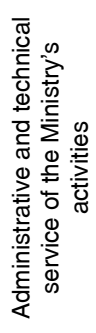 \\
\hline$\stackrel{\oplus}{\oplus}$ & $\stackrel{+}{\oplus}$ & $\dot{\nabla}$ & $\check{f}^{-}$ & $\underset{f}{+}$ & ம் & $\dot{\circ}$ & ָ̦ & 户ூ \\
\hline
\end{tabular}




\section{Allocation of expenditure for budget tasks and consolidation of expenditure in performance budgeting}

Budget tasks are "modules" which transform expenditure from a traditional budget into a performance budget. The two types of budgets are linked by means of budget classification chapters, those links being generally complex. A budget task includes usually expenditure grouped in several chapters of the budget classification, whereas one chapter, on the other hand, is a part of several budget tasks. It refers mainly to chapter 75001 "Offices of central government administration bodies" and chapters "Other activity", where the last two digits are 95 (e.g. 75095, 92695).

Allocation of expenditure to budget tasks is defined by the Directive of the Minister of Finance of 18 May 2007 on the specific manner, procedure and deadlines for developing the materials to the 2008 draft budget act - the so-called budget notification 2008 - Appendix 58. Detailed principles of developing materials for the draft budget act 2008 Chapter 5. List of tasks Item 72 addresses the planning of expenditure by budget tasks.

According to the principles defined in the budget notification, the major tasks of given controller's activity are assigned expenditure classified in individual chapters of the performance budget to essential activities, the so-called essential sections (e.g. section 926 - Physical education and sport, section 803 - Higher education, section 921 - Culture and protection of national heritage), as well as the expenditure in section 750 - Public administration, incurred in direct relation to performance of those tasks. It refers mainly to the following types of expenditure: personnel costs (paragraphs 401, 402, 403, 410, 411, 412, 413, 414, 417), other current expenses (paragraphs 421, 430, 441, 442), and capital expenditure (paragraphs 605, 606) incurred by units responsible for performing the tasks.

In practice, depending on the financial and accounting system used by individual controllers, in the case of section 750 "Public administration" the essential tasks include:

1) only personnel costs, estimated in a simplified way with the following formula:

$$
W O Z_{i}=\frac{W O}{L P} \times L P Z_{i} \text {, where: }
$$

$\mathrm{WOZ}_{\mathrm{i}}$ - personnel costs allocated to a given task,

WO - personnel costs incurred by the analyzed main controller,

LP - number of employees working for the controller,

$\mathrm{LPZ}_{\mathrm{i}}$ - number of employees working on a given task; 
2) only personnel costs, in the planned including salaries and charges for employees working on a given task;

3) total amount of current expenditure;

4) current and capital expenditure.

Due to the extent of the project, in the first stage of implementation of performance budgeting, individual approaches of certain controllers to the allocation of expenditure from Section 750 to individual tasks were accepted. Simplifications made at this stage were inevitable. It triggered off, however, the evolution of accounting principles used by individual controllers. The financial and accounting services of ministries have already begun works on the modification of their recording systems so as to provide information on all the direct costs of individual budget tasks thus enabling the controllers to estimate the costs of operations of individual departments and units. Budget expenditure is related mainly to task performance and activity of the essential departments. Lack of information about the administrative costs they generate affects efficient management, including control over their legitimacy.

After adjustment of accounting systems aimed at providing the information on direct costs generated by individual budget tasks, the next stage will involve implementation of the full cost accounting based on the activity based costing.

The principle of consolidation in a performance budget means "showing in the performance budget the expenditure incurred by those institutions, aimed at performance of a given task or subtask after their mutual settlements have been eliminated (e.g. subsidies from the ministry to an earmarked fund). It means including in the performance budget also own earmarked funds and the so-called government agencies as sources of financing for a given task or subtask." ${ }^{15}$. Moreover, in certain cases the extra-budget sources of financing include for instance:

- accounts of own income (the Ministry of Finance, the Ministry of State Treasury, the Ministry of Foreign Affairs, the Public Procurement Office)

- foreign sources other than structural funds of the European Union (the Office of the Committee for European Integration, the Ministry of Environment, the Ministry of National Defense, the Minister of Labor and Social Policy).

It shows that including earmarked funds and government agencies in the budget act does not exhaust the sources of financing for public tasks.

Below the list of 14 institutions, for which consolidated financial plans were prepared, is presented:

1. Ministry of Interior and Administration

T. Lubińska, Budżet..., op.cit. pp. 45-46. 
2. Ministry of Finance

3. Ministry of Economy

4. Minister of Environment

5. Office of the Committee for European Integration

6. Ministry of Culture and National Heritage

7. Ministry of Sport and Tourism

8. Ministry of Transportation

9. Ministry of Science and Higher Education

10. Ministry of National Defence

11. Ministry of Labour and Social Policy

12. Minister of Treasury

13. Ministry of Foreign Affairs

14. Public Procurement Office

The share of expenditure financed with extra-budget sources in the consolidated expenditure was ranging from $0.27 \%$ in the Ministry of Foreign Affairs (additional sources: accounts of own income) to $95.39 \%$ in the Ministry of State Treasury (four earmarked funds and an account of own income). 


\section{Streszczenie}

Obecnie polskie Ministerstwo Finansów kontynuuje prace nad budżetem zadaniowym w oparciu o metodologię zaprezentowaną w tym artykule. Po raz pierwszy w Polsce przygotowano trzyletnią projekcję wydatków budżetu państwa. Dalsze prace będą skupiały się na ustaleniu priorytetów i powiązaniu ich z wydatkami. W efekcie zostanie przedstawiona druga wersja budżetu zadaniowego, z którego będą pokrywane wszystkie wydatki, jak również zostanie przedstawiona wieloletnia projekcja budżetu państwa. 